\title{
Beauty, Disinterested Pleasure, and Universal Communicability: Kant's Response to Burke
}

\section{Bart Vandenabeele}

Kant's account of aesthetic disinterestedness can be understood, or so I shall argue, as a critical response to Burke's account, and although it is (at least to a certain extent) reconcilable with Burke's psycho-physiological theory, it nonetheless repudiates the latter's empiricist identification of the agreeable and the beautiful. ${ }^{1}$ For, whilst Kant emphasises the social nature of the beautiful, he nevertheless argues (contra Burke and other empiricists) that the grounds of our pleasure in the beautiful are a priori (see KU, AA 05: 347.01-03).

Since Kant's ambitions in the Critique of Judgment are notoriously vast, I can hardly pretend that Kant's aesthetic theory is a response only to Burke's views. It is not only impossible to discuss the historical context of Kant's third Critique in a single essay, but it would also be absurd to reduce Kant's treatment of aesthetics to a response to merely one author. Kant not only criticizes Edmund Burke, but also Francis Hutcheson, David Hume, Lord Kames, Alexander Gerard, Alexander Baumgarten, and several others. Nevertheless, I do want to suggest that it can be illuminating to read Kant's attempt to ground our pure judgments of taste in a priori principles as a response to Burke's psycho-physiological theory of beauty.

The first part of this essay, then, is devoted to a discussion of Burke's and Kant's views of aesthetic pleasure, especially in the beautiful, in order to show that Kant's view of the disinterestedness of aesthetic satisfaction or liking (Wohlgefallen) can be interpreted as a critical response to Burke's failure properly to distinguish between the beautiful and the agreeable. I discuss some important problems in Kant's theory of aesthetic disinterestedness, and argue that Kant, contra Burke, grounds the disinterestedness of aesthetic pleasure in the heightened cognitive activity of understanding and imagination. The second part centres on the social values of aesthetic judgment and experience. Although Kant (wrongly) holds that the universal communicability of aesthetic judgments logically follows from the disinterested character of the pleasure upon which they are based, Kant's emphasis on the a priori validity of judgments of beauty can be viewed, or so I shall argue, as a rebuttal of the kind of empiricist arguments that Burke offers to justify the social nature of the experience of beauty.

\footnotetext{
${ }^{1}$ There can be no doubt that Kant knew Burke's Enquiry well. Moses Mendelssohn published a detailed review of Burke's book in 1758, Gotthold Lessing started but did not complete a German translation, and Christian Garve completed a translation in 1773, which was published by Johann Friedrich Hartknoch, Kant's own publisher in Riga.
} 
Thus, Kant's analysis of the transcendental capacity for universal communicability (allgemeine Mittheilbarkeit) functions as an ideal gauge to assess the aesthetic pleasure's disinterested nature and arguably grounds the qualitative distinction between the agreeable and the beautiful, whereas Burke's psycho-physiological arguments cannot. In the third section of this essay, I want to substantiate the claim that the requirement of universal communicability is not a mere addition to or specification of the requirement of universal validity and is far more relevant to an adequate characterisation of the beautiful than has customarily been assumed. I shall argue, broadly, that the "exemplary necessity" of pure judgments of taste, if understood correctly, reveals beauty's primordial social significance, enabling us to become alive to a profound universal solidarity between aesthetic subjects.

\section{Burke and Kant on Pleasure and Disinterestedness}

According to Burke, aesthetic pleasure can occur in at least two distinct ways. Something can be positively pleasurable and negatively pleasurable. Pleasure and pain are, Burke contends, no mere relations that could only exist in contrast to some previous state of mind: there are pleasures and pains "of a positive and independent nature" (Enquiry, I, 4, 35) 2 , and the diminution or cessation of pain does not result in positive pleasure, but in, what Burke calls, delight. Delight is related to privation, i.e., it is a pleasure "which cannot exist without a relation [...] to pain" (Enquiry, I, 4, 36). The beautiful is the aesthetic variant of positive pleasure, whereas our pleasure in the sublime is the aesthetic variant of relative pleasure, i.e. so-called delight. Our delight in the sublime - "the strongest emotion which the mind is capable of feeling" (Enquiry, I, 7, 39) - belongs to the passions of self-preservation. Sublime delight can arise only when there is danger, and terror is felt: "A mode of terror, or of pain, is always the cause of the sublime" (Enquiry, IV, 8, 134). The emotion of terror is closely related to privation of some sort: solitude as the privation of society, silence as the privation of sound, darkness as the privation of light. The feeling of the sublime occurs when this privation is suspended and the fear or terror is postponed. We are threatened by loss: language, light, sound, life, everything threatens to disappear, and then, this terror of nothingness, this feeling of losing everything is suspended, and we experience delight. We experience the delight of being deprived of those privations. No moral catharsis occurs, as Aristotle thought. The delight in the sublime offers no moral purification or elevation, but intensifies our affective capacities, and heightens our sensitivity.

\footnotetext{
${ }^{2}$ Burke's Enquiry into the Sublime and Beautiful is cited from Burke, Edmund: A Philosophical Enquiry into the Sublime and Beautiful. Edited with an introduction and notes by James T. Boulton. London 2008. Roman numbers refer to parts; Arabic numbers to sections and pages.
} 
Whereas the sublime is bound up with our sense for self-preservation and our fear of losing our capacities to live our own lives, the beautiful is a positive pleasure that is grounded in our social capacities and our desire to live with others. Not surprisingly, Burke connects the beautiful with love, which is "that satisfaction which arises to the mind upon contemplating anything beautiful" and needs to be distinguished from desire or lust, "which is an energy of the mind, that hurries us on to the possession of certain objects, that do not affect us as they are beautiful, but by means altogether different." (Enquiry, III, 1, 91) Beauty is a social quality, "for where women and men, and not only they, but when animals give us a sense of joy and pleasure in beholding them, (and there are many that do so) they inspire us with sentiments of tenderness and affection towards their persons; we like to have them near us, and we enter willingly into a kind of relation with them, unless we should have strong reasons to the contrary." (Enquiry, I, 10, 42f.)

Kant not only reacts against the rationalists who wrongly 'intellectualize' aesthetic experience by assimilating the beautiful to perfection ${ }^{3}$, but also attacks the advocates of an empiricist and physiological approach, and especially Burke, since Kant says that he "deserves to be named as the foremost author in this sort of approach". ${ }^{4}$ The first, most obvious, reason for this repudiation of Burke's "physiological exposition" (ibid.) is that it cannot distinguish properly between the feelings of the agreeable and the beautiful. On the physiological view, the difference is merely a difference in degree and not in quality. The second is that this approach cannot account for, what Kant calls, the "pluralistic" nature of aesthetic judgments (KU, AA 05: 278.20), i.e., the idea - which Kant shares with rationalist predecessors such as Mendelssohn and Baumgarten - that in matters of aesthetic taste, there is a genuine "reason to have controversy about taste, not merely to shrug one's shoulders and say 'to each his own': because judgments of taste rest upon some sort of judgment of the object, specifically of the object's form". ${ }^{5}$ Thus, contra Burke, Kant argues that aesthetic judgments justifiably make claims to universal validity. We value beauty neither merely because of our own private or "egoistic" (KU, AA 05: 278.18) interests, and nor because, as Burke holds, beauty stimulates our social passions, such as love. We experience and appreciate beauty as a priori shareable with others who possess similar

\footnotetext{
${ }^{3}$ For an excellent account on the influence of rationalism on Kant's aesthetics, see Zuckert, Rachel: "Kant's Rationalist Aesthetics". In: Kant-Studien 98, 2007, 443-463.

4 "[...] der in dieser Art der Behandlung als der vornehmste Verfasser genannt zu werden verdient" (KU, AA 05: 277.05-06). Translations of the KU are based on Werner S. Pluhar's (Indianapolis 1987) and Paul Guyer's and Eric Matthews' (Cambridge 2000). I have modified these translations where it seemed appropriate.

${ }^{5}$ Zuckert, Rachel: Kant on Beauty and Biology. An Interpretation of the Critique of Judgment. Cambridge 2007, 176.
} 
discriminatory and judgmental faculties. I shall return to the latter issue in the second part of my essay, and now concentrate on the former: the distinction between the agreeable and the beautiful, and why Kant believes that disinterestedness is a suitable criterion adequately to distinguish between both feelings.

Kant agrees with the empiricists that "gratification and pain are always ultimately corporeal $[\ldots]$ because life without the feeling of the corporeal organ is merely consciousness of one's own existence, but not a feeling of well- or ill-being"6, but he wholly rejects the empiricist assimilation of pleasure in the beautiful to merely agreeable sensation.

How does Kant distinguish between the feelings of the beautiful and the agreeable? Agreeable sensations are subjective responses, which depend upon our personal preferences and aversions. Pleasure in the agreeable is therefore, Kant argues, "interested", whereas pleasure in the beautiful is not. In section 2 of the $\mathrm{KU}$, Kant writes that "the satisfaction that we combine with the representation of the existence of an object is called interest. Hence such a satisfaction always has at the same time a relation to the faculty of desire, either as its determining ground or else as necessarily interconnected with its determining ground." In his insightful paper on "Kant on Pleasure in the Agreeable", Nick Zangwill attempts to clarify this as follows: "if a pleasure is an 'interest', in Kant's sense, it means that it bears an intimate relation to a desire (that is to say, a concern with real existence). An 'interest' is a pleasure that has some kind of necessary connection with desire. A pleasure is 'disinterested' if it has no such necessary connection with desire". 8 it is worth noting that Kant's conception of interest is broader than the idea of self-interest that Kant's reference to the capacity of desire (Begehrungsvermögen) seems to suggest; thus, pleasures in the good - moral pleasures - are as "interested" as pleasures in the agreeable, for they presuppose that the object is judged according to external standards of utility or in

\footnotetext{
${ }^{6}$ "[...] daß [...] immer Vergnügen und Schmerz zuletzt doch körperlich sei, es mag nun von der Einbildung,oder gar von Verstandesvorstellungen anfangen: weil das Leben ohne dasGefühl des körperlichen Organs bloß Bewußtsein seiner Existenz, aber kein Gefühl des Wohl- oder Übelbefindens". (KU, AA 05: 277.30-32-5: 278.1-2)

7 "Interesse wird das Wohlgefallen genannt, was wir mit der Vorstellung der Existenz eines Gegenstandes verbinden. Ein solches hat daher immer zugleich Beziehung auf das Begehrungsvermögen, entweder als Bestimmungsgrund desselben, oder doch als mit dem Bestimmungsgrunde desselben nothwendig zusammenhängend." (KU, AA 05: 204.22-26)

${ }^{8}$ Zangwill, Nick: "Kant on Pleasure in the Agreeable". Journal of Aesthetics and Art Criticism 53, 1995, 167.
} 
relation to ends that are external to it. Kant actually uses the term "interest" throughout his writings in at least five distinct senses: ${ }^{9}$

(i) pleasure in the object's existence

(ii) rational or sensory desire, the satisfaction of which is pleasant

(iii) self-interest: direct promotion of one's preservation, welfare, or happiness

(iv) that by which reason becomes practical or determines the will: the attempt to achieve a moral or prudential end

(v) active interaction or engagement with an object

Corresponding to these five senses of 'interest', the senses of 'disinterestedness' are the following ${ }^{10}$ :

(1) not taking pleasure in the object's existence

(2) not having a rational or sensory desire

(3) not directly promoting one's preservation, welfare, or happiness

(4) not attempting to achieve a moral or prudential end

(5) not being partial

This should suffice to see that the Kantian topics of interest and disinterestedness are extremely complex, and unfortunately Kant does not always clearly distinguish between the different senses of 'interest' and 'disinterestedness' he employs. Here we shall focus on Kant's idea of aesthetic disinterestedness, and more specifically still, on his analysis of judgments of beauty, hence leaving aside the question of the sublime's disinterestedness. ${ }^{11}$

Kant contends that our pleasure in the agreeable depends upon the real existence of the object which occasions it, that is to say, the 'appearance' of agreeableness is not sufficient to afford us pleasure. In the case of pure judgments of taste, however, "it is readily seen that to say that the object is beautiful and to prove that I have taste what matters is what I make of this representation in myself, not how I depend on the existence of the object". ${ }^{12}$ I take Kant to mean that a particular interest in what kind of object it is, whether or not it is relevant to our aims, wants or desires, even in whether it is real or not, are not required for our pure aesthetic judging and enjoying the object. And because pure aesthetic

\footnotetext{
${ }^{9}$ See Clewis, Robert: The Kantian Sublime and the Revelation of Freedom. Cambridge 2009, 146-147, to which I am indebted. Clewis also mentions the references to Kant's work.

${ }^{10}$ See Clewis: The Kantian Sublime, 149.

${ }^{11}$ See Clewis: The Kantian Sublime, chapter 4.

12 "Man sieht leicht, daß es auf das, was ich aus dieser Vorstellung in mir selbst mache, nicht auf das, worin ich von der Existenz des Gegenstandes abhänge, ankomme, um zu sagen, er sei schön, und zu beweisen, ich habe Geschmack." (KU, AA 05: 205.10-13)
} 
judging is solely grounded in the object's singular appearance and not in any further personal interests, the pleasure it affords can be characterised as genuinely disinterested.

Two things must be specially noted here: first, disinterestedness is an aspect of the pleasure on which a pure judgment of taste is based, and secondly, the disinterested quality of the pleasure is a logical (and not a psychological) requirement of pure judgments of taste, which arguably enables us to distinguish them from judgments of the agreeable and the good. It may, of course, be that some intellectual, sensual and moral considerations supervene upon our aesthetic judging and liking. But this psychological fact is not an argument against Kant's analysis. On the contrary, those considerations may well be psychologically involved in our aesthetic judging, but Kant's point is the logical one that such elements are not necessary preconditions of aesthetic judgment. And whilst disinterestedness may sometimes take on a psychological character, since (as Kant insists) "a judgment of taste is merely contemplative" ${ }^{13}$, it can none the less be justly claimed that the above mentioned psychological factors are not necessary requirements of judgments of pure beauty.

Now, Kant further complicates matters by insisting not only that our pleasure in beautiful objects cannot originate from any interest, but also, and more importantly, that our pleasure in the beautiful does not create any interest in the object either. Agreeable objects, say Belgian chocolates, that cause pleasure merely because of their sensible properties, are said to "gratify [vergnügt]" someone (KU, AA 05: 210.04). More specifically, when I enjoy eating a Belgian chocolate, "I am not granting mere approval: the agreeable produces an inclination" and "arouses a desire for objects of the same kind"14. Kant, moreover, adds that "all interest presupposes a need or gives rise to one; and, because interest is the determining ground of approval, it no longer leaves the judgment on the object free." ${ }^{15}$ Hence, the basic difference between the agreeable and the beautiful must be that the agreeable gives rise to a desire for similar objects, whereas the feeling of the beautiful does not.

To make sense of this, we must recall that Kant contends that, unlike the beautiful, pleasure in the agreeable is connected with the existence of the object that caused the agreeable sensation in the first place - i.e., the first sense of disinterestedness mentioned

\footnotetext{
13 "[...] ist das Geschmacksurtheil bloß contemplativ [...]" (KU, AA 05: 209.12-13)

14 “[...] daß es durch Empfindung eine Begierde nach dergleichen Gegenstande rege macht [...]" (KU,
} AA 05: 207.02-03)

15 "Alles Interesse setzt Bedürfnis voraus, oder bringt eines hervor; und als Bestimmungsgrund des Beifalls läßt es das Urtheil über den Gegenstand nicht mehr frei sein." (KU, AA 05: 210.20-22) Nick Zangwill rightly emphasises that this 'unfreedom' of the pleasure in the agreeable is "a matter of the causes of the pleasure. It does not detract from what Kant is saying about the way that pleasure then provokes desire, via a representation. If a pleasure is unfree, it is unfree because of the way it is caused, not because of what it causes." ("Kant on Pleasure in the Agreeable", 170.) 
above. Thus Kant plausibly argues that, if the satisfaction caused by the object leads to a desire for more similar objects (e.g. more Belgian chocolates), then this implies that the initial satisfaction was connected with the existence of the first object. ${ }^{16}$ For how else could it produce this desire (or inclination) for more objects that are thought to be similar?

This contrast between the pleasures in the agreeable and the beautiful raises a number of worries. First, how plausible is Kant's claim that pleasures in the agreeable are necessarily productive of desire for more similar objects? Not all pleasures in the agreeable provoke the desire for more objects of the same kind. Put more concretely, as Nick Zangwill asks, "what about the last piece of chocolate that we enjoy before we have had enough? [...] The sight of yet more chocolate can soon come to disgust one. It seems that the last pleasurable piece of chocolate does not provoke a desire for more of the same". ${ }^{17}$ Thus, although Kant may be right that many kinds of agreeable sensations are "more-ish" or productively interested, not all pleasures in the agreeable are.

There is a second possible objection to Kant's distinction, viz. that Kant, as Paul Guyer notes, instead of distinguishing between kinds of pleasure, merely supplies "a distinction between feelings of pleasure and all other kinds of sensation". ${ }^{18}$ However, Kant's view of pleasure is more complicated than Guyer ${ }^{19}$ allows. By defining pleasure as feeling instead of sensation, Kant is not merely saying that pleasure is some peculiar kind of sensation, i.e. a subjective sensation "which cannot become an element of cognition at alr"20, since it does not refer to objects. The subjective nature of Kant's notion of feeling is much more profound than that. Rachel Zuckert ${ }^{21}$, amongst others ${ }^{22}$, suggests (rightly) that

\footnotetext{
${ }^{16}$ This does not entail that Kant is offering a purely causal account of the interestedness of pleasure in the agreeable. I here agree with Zangwill: "Once we see that Kant is not offering a purely causal account of the interestedness of pleasure in the agreeable, we will be less prone to think that he thinks that pleasure in the beautiful is disinterested because the pleasure bears no causal relation to the objects that we find pleasurable and thus call beautiful. If Kant did think this, it would make his claim that pleasure in the beautiful is disinterested very implausible. But fortunately Kant holds no such view." ("Kant on Pleasure in the Agreeable", 169.)

${ }^{17}$ Zangwill: "Kant on Pleasure in the Agreeable", 172.

${ }^{18}$ Guyer, Paul: Kant and the Claims of Taste. Cambridge 1997, 153.

${ }^{19}$ Guyer: Kant and the Experience of Freedom. Cambridge 1996, 280-1, and Kant and the Claims of Taste, $104 f$.

20 "was gar kein Erkenntnißstück werden kann” (KU, AA 05: 189.26-27)

${ }^{21}$ Zuckert: Kant on Beauty and Biology, 233. I am here indebted to Zuckert's excellent account (233ff.) of the intentional nature of pleasure, yet I do not agree with her identification of the intentionality of pleasure with purposiveness without a purpose. (Cf. infra)

${ }^{22}$ Other commentators who offer a basically intentionalist reading of Kant's conception of aesthetic pleasure include Allison, Henry: "Pleasure and Harmony in Kant's Theory of Taste: A Critique of the
} 
"pleasure is, on Kant's definition, a representation with intentional content, which comprises other representations understood to be modifications of the subject (that is, are themselves not [solely] referred to objects)." ${ }^{23}$ Kant characterises pleasure in the Critique of Judgment as the "consciousness of the causality of a representation with respect to the state of the subject, for maintaining it in that state"24.

Thus, contra Guyer, Kant does not agree with the empiricists, who maintain that pleasure is a kind of primitive idea or raw sensation, but contends that pleasure is a feeling about something, or more accurately, about the continuation of the feeling or the mental state. ${ }^{25}$ Pleasure in eating Belgian chocolates would then be the awareness or "the feeling that the representation of chocolate is 'causing' one to stay in the state of having that representation (of the taste of chocolate)." ${ }^{26}$ Pleasure is thus intimately connected with our "feeling of life" (Lebensgefüh/; Gefühl des Lebens) (KU, AA 05: 204.08; 05: 277.28), i.e., with enjoying the state one finds oneself in when (for instance) experiencing the sensible properties of an object. Thus, on this view, Kant does not consider pleasure a mere "raw feel", as Guyer claims. Pleasure does not need to be referred to objects via empirical concepts or judgments, but is necessarily characterized by intentionality, i.e. "aboutness": it "is about" a subject's mental state. ${ }^{27}$ Therefore, it is aptly called "subjective" by Kant, even though it is not a sensation, but "a second-order, reflexive state with respect both to other mental states and to the position of those states in time, the form of inner sense." ${ }^{28}$ We do not experience

Causal Reading". In: Kants Ästhetik / Kant's Aesthetics / L'esthétique de Kant. Edited by Herman Parret. Berlin 1998, 466-483; Aquila, Richard: "A New Look at Kant's Aesthetic Judgments". In: Essays in Kant's Aesthetics. Edited by Ted Cohen \& Paul Guyer. Chicago 1982, 92f., 95f.; Falk, Barry: "The Communicability of Feeling". In: Pleasure, Preference and Value: Studies in Philosophical Aesthetics. Edited by Eva Schaper. Cambridge 1983, 57-85; Fricke, Christel: "Explaining the Inexplicable". In: Noûs 24, 1990, 45-62; Fricke, Christel: Kants Theorie des reinen Geschmacksurteils. Berlin. 1990; Schaper, Eva: Studies in Kant's Aesthetics. Edinburgh 1979, 46f., 52.

${ }^{23}$ Zuckert: Kant on Beauty and Biology, 233.

24 "Das Bewußtsein der Causalität einer Vorstellung in Absicht auf den Zustand des Subjects, es in demselben zu erhalten [...]"(KU, AA 5: 220.9-11)

${ }^{25}$ Zuckert: Kant on Beauty and Biology, 233. See also Zöller, Günther: "Towards the Pleasure Principle: Kant's Transcendental Psychology of the Feeling of Pleasure and Displeasure". In: Akten des 7. Internationalen Kant-Kongresses. Bonn 1991, 817ff.

${ }^{26}$ Zuckert: Kant on Beauty and Biology, 233.

${ }^{27}$ See Aquila, Richard: "A New Look at Kant's Aesthetic Judgments". In: Essays in Kant's Aesthetics. Edited by Ted Cohen \& Paul Guyer. Chicago 1982, 87-114.

${ }^{28}$ Zuckert: Kant on Beauty and Biology, 236. See also Allison, Henry: Kant's Theory of Taste. Cambridge 2001, 69-70. 
pleasure primarily as the separate effect of something, but we take pleasure in something (ibid.), e.g., in drinking a glass of Chablis, in eating oysters, in sinking into a hot bath, etc.

For Kant, an interest entails taking pleasure in the actual existence of the object. At first sight, this might seem to obscure the difference between pleasure in the beautiful and the agreeable. It seems as if Kant claims that the agreeable produces an interest in (or desire for) further experiences of the same sort, whereas the beautiful does not, and this (to say the least) seems highly implausible. Yet, while Kant does hold that any pleasure will tend towards maintaining itself, the tendency to prolong itself is not an interest in Kant's sense. By emphasising that the agreeable is connected with an interest in objects of the same kind, whereas the beautiful is not, Kant intimates that the former provokes not a desire for more similar experiences, but for more objects of the same kind, i.e. objects that will offer such (agreeable) experiences. On the other hand, pleasure in the beautiful is wholly disinterested, since it may (and usually will) urge us to maintain in the specific state of aesthetic pleasure we find ourselves in, but does not necessarily stimulate a desire for the actual existence of the object, since our pleasure in a beautiful object stems from the contemplation of the object's form alone and is grounded in the free yet harmonious "play" of imagination and understanding (Cf. infra).

In any case, despite the fact that bodily pleasures such as a sexual orgasm or tasting absinthe may seem to suggest otherwise, Kant suggests that pleasures are not free floating sensations but reflexive, second-order feelings. Contrary also to his earlier view defended in the $\mathrm{KpV}$, in the $\mathrm{KU}$ he will claim that not all pleasures are sensations or, more accurately, sensory pleasures are, contra the empiricists, not the only kind of pleasure - although he does retain the view that when pleasures are "sensations" (pleasures in the agreeable or "enjoyments" as he sometimes calls them), then they are "the same in kind, differing only in degree". ${ }^{29}$ Of course, he concurs with the empiricists that sensory pleasure is a kind of pleasure, but repudiates their privileging of sensory (or bodily) pleasure - the sensuous pleasure we take in enjoying a cognac or a hot shower - as a model for all other kinds of pleasure. Hence, Kant maintains that pleasure in the agreeable is only a sub-class of pleasure; this is the kind of sensory pleasures that we share with animals (Cf. KU, AA 05: 210.06). Thus, there is no reason to privilege agreeable sensations over other kinds of pleasure.

As we saw earlier, Kant rashly claims that all pleasures in the agreeable are productively interested, i.e. arouse the desire for more objects of the same kind. "Sated" pleasures, though, such as orgasms, do not - at least not immediately - provoke the desire

\footnotetext{
${ }^{29}$ Zuckert: Kant on Beauty and Biology, 240.
} 
for more similar pleasures. ${ }^{30}$ Yet what about Kant's insistence that pleasure in the beautiful is devoid of interest, i.e. is only related to the subject's feeling of life (LebensgefühI), and is completely independent of the existence of the object? Kant argues that pure aesthetic pleasure is directed to the representation of the object, as opposed to the connection between the subject and the "real existence" of the object. For pure aesthetic judgment, a representation of the object is all that is required, whereas in an "interested" response to an object, its actual existence will be involved. In a rather amusing note, taken from his Reflexionen from the mid-1770s, Kant furnishes examples of the sorts of interest in existence that must be excluded from pure aesthetic appraisals:

Taste shows itself if one does not choose merely on account of usefulness. Therefore, a porcelain button is more beautiful than a silver one. The beauty of lace consists in the fact that it does not last long. Clothes are therefore chosen of delicate colours, because they are perishable. Flowers have their beauty in their perishability. (Nature has given the least beauty to that which is enjoyable because it nourishes: cows, bees, swine, sheep; to that which refreshes in enjoyment, somewhat more: fruit; that which smells nice, more: and that which can merely please the eye, the most. ${ }^{31}$

According to Guyer, "this passage misinterprets the requirements of disinterestedness", as it not merely separates taste from practical dependence, but in fact "proposes an actual conflict between beauty and practicality". ${ }^{32}$ Technically speaking, Guyer is right. Disinterested contemplation does not necessarily imply an asymmetry of beauty and practicality: a kind of syncretism of both remains possible. Yet Kant only points out that there is quite often a real conflict between taste and usefulness, or beauty and practicality, which can serve as a corroborating fact about the disinterestedness of the pure judgment of taste. The inverse relationship between beauty and usefulness is not a necessary consequence of the judgment's disinterestedness, although this does not subsequently rule out the possibility of an actual conflict between both either.

\footnotetext{
${ }^{30}$ Zangwill: "Kant on Pleasure in the Agreeable", 174.

31 "Der Geschmak zeigt sich darin, daß man etwas auch nicht lediglich um der nützlichkeit willen wählt. So ist ein porcellainer Knopf schoner als ein silberner. Die Schönheit der Spitzen besteht darin, daß sie lange halten. Kleider werden darum von delicaten Farben gewählt, weil sie verganglich sind. Die Blumen haben ihre Schonheit von der Verganglichkeit. Die Natur hat dem geniesbaren, was ernährt, die mindeste Schonheit gegeben. Kuh, apis, Schwein, Schaf. Dem erfrischenden im Genus etwas mehr: obst. Dem Wohlrichenden mehr, und dem, was blos die Augen vergnügen kan, die meiste." (Refl 868, AA 15: 382.06-15)

${ }^{32}$ Guyer: Kant and the Claims of Taste, 174.
} 
Although, as we have seen, disinterestedness is first and foremost a logical requirement of judgments of beauty and does not primarily refer to any specific aspect of a mental state, Kant does develop some psychological aspects of the way in which we experience and enjoy beauty. The disinterestedness of pure judgments of taste will, first, be related to what Kant calls the 'feeling of life ${ }^{33}$ of the subject - which is why Kant calls the pleasure in the beautiful satisfaction of liking (Wohlgefallen) instead of gratification (Vergnügen). Secondly, and more importantly, Kant contrasts pure beauty with the graceful, lovely, enchanting, enjoyable, etc., arguing that judgments of pure beauty are "independent from charm and emotion" ${ }^{34}$ and that our pleasure in beautiful objects is not due to a mere physiological response to an object's qualities but arises from "a feeling of the free play of the faculties of cognition"35. Kant further insists that our aesthetic judging of the representation through which the object is given, precedes the pleasure in it, and is the ground of this pleasure in the harmony of the faculties of cognition, and he adds that "on that universality of the subjective conditions of the judging of objects alone is this universal subjective validity of liking, which we combine with the representation of the object that we call beautiful, grounded"36. I shall not go into all the intricacies that commentators have addressed in connection with the arguments that Kant provides to ground his distinction between merely agreeable sensations and genuine feelings (and judgments) of beauty. It should now be clear, however, that Kant's insistence on the logical requirement of disinterestedness ultimately and fundamentally depends upon his epistemology. More specifically, because disinterested aesthetic pleasure "is not grounded in any concept [...], no other consciousness of it is possible except through sensation of the effect that consists in the facilitated play of both powers of the mind (imagination and understanding), enlivened through mutual accord."37

\footnotetext{
${ }^{33}$ For an excellent treatment of the parallels and differences between beauty's 'feeling of life' (Lebensgefühl) and morality's 'feeling of spirit' (Geistesgefühl), which is not a feeling of sense but is still in some way palpable, see Zammito, John: The Genesis of Kant's Critique of Judgment. Chicago 1992, 292-305. Interestingly, Kant also uses the term Geistesgefühl and not Lebensgefühl in connection with the feeling of the sublime.

34 "[...] von Reiz und Rührung unabhängig” (KU, AA 05: 223.02-03)

35 “[...] eines Gefühls des freien Spiels der Vorstellungskräfte [...]" (KU, AA 05: 217.24)

36 “ [...] auf jener Allgemeinheit aber der subjectiven Bedingungen der Beurtheilung der Gegenstände gründet sich allein diese allgemeine subjective Gültigkeit des Wohlgefallens, welches wir mit der Vorstellung des Gegenstandes, den wir schön nennen, verbinden [...]” (KU, AA 05: 218.11-14)

37 “ [...] und bei einem Verhältnisse, welches keinen Begriff zum Grunde legt (wie das der Vorstellungskräfte zu einem Erkenntnißvermögen überhaupt), ist auch kein anderes Bewußtsein desselben, als durch Empfindung der Wirkung, die im erleichterten Spiele beider durch wechselseitige
} 
Thus Kant's notion of aesthetic disinterestedness cannot be properly understood without reference to the reflective activity from which it arises: that our judgment is a genuine judgment of beauty cannot be found out unless we are able to retrieve the epistemic (and, hence, non-physiological) basis of the feeling of pleasure we experience and upon which we base our judgment. Only if the pleasure is not merely a personal physiological response to external stimuli but can be attributed correctly to the purposeful play of our cognitive capacities can it be inferred that our judgment is a pure judgment of taste. That Kant remains extremely vague about the method and outcome of such an introspective investigation is unfortunate, but is not our primary concern here. ${ }^{38}$ Far more crucial is that the disinterested character of the pleasure on which our aesthetic judgment is based ultimately depends upon the object's potential to stimulate our cognitive faculties, thereby enabling us to recognise the object or, more specifically, the object's form as purposive in relation to "cognition generally" (see KU, AA 05: 290; 292f.). That is to say, while beauty can only be consciously recognised through the pleasure we feel in it, this pleasure itself is (again contra Burke) ultimately grounded in heightened purposeful cognitive activity, involving the mutual quickening of understanding and imagination. ${ }^{39}$

Only now can we genuinely grasp Kant's insistence on the disinterestedness of pure aesthetic pleasure: it is not based on any desire for the object as such, yet it is clearly not conceivable without its being grounded in an unusually lively and purposeful co-operation of the cognitive powers (or, what Kant calls, the recognition of the formal purposiveness of our pleasure). An aesthetic judgment is, as Paul Crowther puts it, "teleological in a subjective sense. On the one hand, the judgment has 'formal finality' in so far as beautiful configuration appears as if it has been created for the express purpose of stimulating cognitive exploration; on the other hand, the free harmonious interaction of understanding and imagination which it brings about is 'subjectively final' in relation to cognition generally. This means that in renewing cognition's structural basis, it can be regarded as teleologically significant in

Zusammenstimmung belebten Gemüthskräfte (der Einbildungskraft und des Verstandes) besteht, möglich." (KU, AA 5: 219.11-16)

${ }^{38}$ I have discussed this elsewhere. See my "The Subjective Universality of Aesthetic Judgements Revisited". In: British Journal of Aesthetics 48, 2008, 410-425.

${ }^{39}$ Kant's analysis appears to entail that everything must be considered beautiful, for the apprehension of every manifold involves the harmony of the cognitive powers. See, for instance, Meerbote, Ralf: "Reflections on Beauty". In: Essays in Kant's Aesthetics. Edited by Ted Cohen \& Paul Guyer. Chicago 1982, 81ff. Following Ameriks, I would suggest that not every synthesis of imagination conforms to the optimal degree of 'attunement' between imagination and understanding that allegedly grounds pure beauty. See Ameriks, Karl: "How to Save Kant's Deduction of Taste". In: Journal of Value Inquiry 16, 1982, $299 f$. 
relation to the attainment of knowledge - even though it i[s] not, in itself, a claim to knowledge." 40 Unfortunately, because Kant essentially confines himself to showing that our pleasure in the beautiful differs from the agreeable and the good, which are clearly connected with interest, he leaves us with no convincing independent argument that pleasure in the beautiful is actually disinterested. By no means does the fact that the pleasure in the beautiful is different from the agreeable and the good, which are definitely connected with interest, entail that the pleasure in the beautiful is disinterested. Thus, instead of offering us a convincing account of the disinterestedness of aesthetic pleasure, he leaves us with the quite controversial idea that pleasure in the beautiful does not originate from nor create any interest. It is hard to see, however, why this should be so. For, after all, appreciating beauty does give rise to all sorts of interests - one may desire to own the artwork one finds beautiful or to make love to the woman one finds beautiful or develop a religious interest on the basis of one's aesthetic pleasure in nature. Kant was surely aware of this, and whereas he may still be right that all those kinds of interests (be they intellectual, moral or sensual) which we may develop as a result of enjoying beauty cannot provide the necessary determining ground of pure judgments of taste, most of our judgments of beauty are not pure but are mingled with other interests - they are cases, as Kant would urge, of "dependent beauty".

Now, before turning to the issue of the social values of beauty, it should be clear that - contra Burke's empiricist identification of beauty and agreeableness - Kant's idea of disinterested beauty cannot be understood without recourse to the reflecting activity of our cognitive faculties on the (form of) the judged object and on the ground of our pleasure. Contrary to mere sensory judgments of the agreeable, a judgment of beauty clearly involves cognitive activity, whereby our imagination and understanding produce pleasure or displeasure. Judgments of beauty are reflective judgments, which means that - although they are non-cognitive because they are based on the feeling of pleasure or displeasure and not on any determinate concepts - they presuppose the purposive "play" of our imagination and understanding; and the pleasure we take in the beautiful is rightfully characterised as disinterested only because it is ultimately grounded in the "free harmonious play" of imagination and understanding, which reciprocally enliven each other and purposefully accord. Thus the disinterested quality of our pleasure does not merely refer to but actually arises from a harmonious relation between our cognitive faculties, which is purposive with regard to cognition in general (see KU, AA 05: 217; 05: 222).$^{41}$

\footnotetext{
${ }^{40}$ Crowther, Paul: "The Significance of Kant's Pure Aesthetic Judgment". In: British Journal of Aesthetics 36, 1996, 115.

${ }^{41}$ See also Kneller, Jane: "Kant's Concept of Beauty". In: History of Philosophy Quarterly 3, 1986, 311-324; Prauss, Gerold: "Intentionalität bei Kant”. In: Akten des 5. Internationalen Kant-Kongresses.
} 
We thus arrive at what, on Kant's views, is the distinctive (albeit somewhat paradoxical) source of pure aesthetic pleasure: the disinterestedness of our pleasure in the beautiful is ultimately based upon the interests of the cognitive faculties to engage with and cognitively explore the formal features of an object. By exploring various shapes, contours, and randomly trying out several configurations, they stimulate and enliven one another, without their activity being determined by the application of concepts to the phenomenal unity: "we linger over the consideration of the beautiful" 42 . For Kant, aesthetic reflection somehow attempts to realise the ultimate goals of cognition in the absence of the subsumption of sensory intuitions under determinate concepts. ${ }^{43}$

Thus, "imagination", he contends, "must in the judgment of taste be considered in its freedom [...] not taken as reproductive, as subjected to the laws of association, but as productive and self-active (as originator of arbitrary forms of possible intuitions) ${ }^{p 44}$. To make sense of this, we must recall that in ordinary cognition the imagination operates in the service of the understanding's determining activity: it is not free but produces schemata that enable conceptual determination and identification of objects. The specific reflective nature of aesthetic appreciation precludes, however, the mutual accord of imagination and understanding from resulting in a conceptual determination of the object. On the contrary, the imagination gains a freedom to "play with" the forms and explore and develop ever new configurations and patterns instead of plainly offering the understanding schemata that are to be determined conceptually in order to identify the object. In aesthetic reflection, the imagination gains a freedom that surpasses the subservient role it plays in ordinary cognition, that is to say, "only a subjective correspondence of the imagination and the understanding without an objective one - where the representation is related to a determinate concept of an object - is consistent with the free lawfulness of the understanding (which is also called purposiveness without a purpose) and with the peculiarity of a judgment of taste"45.

Edited by Gerhard Funke. Bonn 1981, 763-771; Savile, Anthony: "Objectivity in Aesthetic Judgment: Eva Schaper on Kant". In: British Journal of Aesthetics 21, 1981, 364-369; Wolterstorff, Nicholas: "An Engagement with Kant's Theory of Beauty". In: Kant's Aesthetics. Atascadero 1991, 105-127.

42 "Wir weilen bei der Betrachtung des Schönen [...]" (KU, AA 05: 222.33)

${ }^{43}$ Cf. infra. See also Hughes, Fiona: Kant's Aesthetic Epistemology: Form and World. Edinburgh 2007, especially chs. 5,7 , and 8 .

44 "Wenn nun im Geschmacksurtheile die Einbildungskraft in ihrer Freiheit betrachtet warden muß, so wird sie erstlich nicht reproductiv, wie sie den Associationsgesetzen unterworfen ist, sondern als productiv und selbstthätig (als Urheberin willkürlicher Formen möglicher Anschauungen) angenommen [...]" (KU, AA 05: 240.24-28)

45 “ [...] eine subjective Übereinstimmung der Einbildungskraft zum Verstande ohne eine objective, da die Vorstellung auf einen bestimmten Begriff von einem Gegenstande bezogen wird, mit der freien 
Despite Kant's sharp distinction between aesthetic (reflective) judgments, which are based on subjective feelings, and cognitive judgments, which are determined by categories of the understanding, pure aesthetic judgments too, then, require the activity of the cognitive faculties, for Kant associates aesthetic judgments, as Guyer puts it, "with the use of the cognitive faculties and the realization of at least the subjective aspect of cognition under special circumstances, circumstances in which one of the ordinary requisites for cognition, the subsumption of objects under determinate concepts, is lacking." ${ }^{46}$ Thus, although Kant is well aware that our reflective engagement with beautiful objects may produce intellectual, empirical and moral interests and might even be conducive to genuine moral behaviour, he shuns any identification of the aesthetic and cognition, even though he nonetheless insists that the free formative activity of our cognitive capacities is intrinsically pleasurable and that aesthetic judgments of beauty cannot be realised without this heightened activity of our cognitive faculties. ${ }^{47}$ This does not imply, however, that - as Fiona Hughes none the less claims - "it is as if our aesthetic appreciation amounted to knowledge", and that "the phenomenon offers no resistance to our apprehension of it. Neither does it appear resistant to our identifying it by a concept." ${ }^{48}$ I would rather suggest that in aesthetic reflection we do not reflect on "what makes an object knowable in the first place", but our imagination plays with the object's form and we reflect on the source of the pleasure we experience through this mental activity. That the co-operative activity of our mental faculties is a necessary condition for cognition neither entails that aesthetic reflection incites a reflection on the

Gesetzmäßigkei des Verstandes (welche auch Zweckmäßigkeit ohne Zweck genannt worden) und mit der Eigenthümlichkeit eines Geschmacksurtheils allein zusammen bestehen können [...]" (KU, AA 05: 241.12-17)

${ }^{46}$ See Guyer, Paul: "Pleasure and Knowledge in Schopenhauer's Aesthetics". In: Schopenhauer, Philosophy, and The Arts. Edited by Dale Jacquette. Cambridge 1996, 113-114.

${ }^{47}$ Jane Kneller argues that "reflection gives rise in aesthetic judgment to a feeling whose universal validity depends upon its independence from practical and theoretical determination. [...] the paradigm case of aesthetic feeling, namely our feelings for the beautiful, depend entirely on conditions of cognition in general. Such feelings not only are independent of practical reason, but their very right to claim universal validity depends on this independence." See Kneller, Jane: "Aesthetic Value and the Primacy of the Practical in Kant's Philosophy". In: Journal of Value Inquiry 36, 2002, 377.

${ }^{48}$ See Hughes, Fiona: "On Aesthetic Judgement and Our Relation to Nature: Kant's Concept of Purposiveness". In: Inquiry 49, 2006, 561. Christel Fricke also defends this tight connection between aesthetic judgments and the possibility of empirical synthesis. See Fricke, Christel: Theorie des reinen Geschmacksurteils, 115 and passim. 
"possibility of empirical schematism", as Hughes would have it, nor, as Avner Baz argues, that Kantian aesthetic theory is merely an expression of a "cognitive craving". 49

Thus, Kant's basic idea seems to be that only in the case of the agreeable we can have empirical knowledge of its causal basis. A physiological response can be the subject of empirical investigation and empirical causal laws, and the agreeableness of the object may be included in the causal nexus that constitutes the "real existence" of the object, whereas the feeling of the beautiful cannot - again contra Burke, who claims that "the appearance of beauty as effectually causes some degree of love in us, as the application of ice or fire produces the ideas of heat or cold" (Enquiry, III, 2, 92). From a Burkean perspective, the beautiful causes the passion of love. Although Burke distinguishes love from desire, and (only) in this sense anticipates Kant's analysis of the disinterestedness of aesthetic pleasure, he fails adequately to justify a qualitative distinction between the beautiful and the agreeable: as an empiricist, he can only account for a difference in degree. Kant not merely holds that Burke's distinction between desire and love is flawed, but also that his physiological explanation of the beautiful cannot account for the universa ${ }^{50}$ validity of judgments of beauty (see $\mathrm{KU}, \mathrm{AA}$ 05: 213). It is to this issue that we now turn.

\section{The Universal Communicability of the Beautiful}

Burke emphasises the social nature of beauty and love. In the 'Introduction to Taste', which was added later, ${ }^{51}$ even insists that his "point in this enquiry is to find whether there are any principles, on which the imagination is affected, so common to all, so grounded and certain, as to supply the means of reasoning satisfactorily about them. And such principles of Taste, I fancy there are" (Enquiry, 'Introduction on Taste', 14). Yet he remains silent on the question of the universality claim of judgments of beauty: he does connect beauty with our 'passions for society', but this has more to do with the passion caused by the experience of beauty, viz. love, than with the appreciation of beauty as such.

Like Burke, Kant argues that, in calling something beautiful, we claim that (in ideal circumstances) everybody ought to take pleasure in it, no matter how many times the assent of others is often enough rejected, and also concurs with Burke and other British empiricists that it can only be an empirical judgment that I perceive and judge an object to be beautiful.

\footnotetext{
${ }^{49}$ See Baz, Avner: "Kant's Principle of Purposiveness and the Missing Point of (Aesthetic) Judgements". In: Kantian Review 10, 2005, 30f.

${ }^{50}$ Kant clearly, though not always consistently, distinguishes between 'universal' and 'general': the latter refers to empirical rules, the former to transcendental ones.

${ }^{51}$ The introduction was added to the second edition of the Enquiry in 1759, most probably in response to David Hume's essay "On the Standard of Taste" (1757).
} 
Kant, however, severely condemns any attempt to dispense with the objectivity claim of pure aesthetic judgments and rejects Burke's contention that beauty is derived solely from sensations that merely depend on our physiological constitution. When we judge something to be agreeable, Kant says, we can accept that others disagree: 'this dish is agreeable to me' is definitely an acceptable expression (see KU, AA 5: 212.09ff.). But when I judge something as beautiful, I cannot claim that it is mere beautiful for me (ibid.): although the judgment is based on a personal feeling of pleasure (Wohlgefallen), we require others to agree with us: a judgment on the beauty of an object is always pluralistic; it completely differs from the agreeable, which is a merely private feeling of gratification (Cf. supra).

Thus, although Kant concurs with Burke's typically empiricist emphasis on the role of the senses in matters of taste and highlights the importance of a personal encounter with the aesthetic object, he rejects his conclusion that our common human physiology aptly grounds the universality claim of pure judgments of taste. Kant attempts to provide a priori foundations for what Burke thought were matters of natural principles, imagination, custom and physiological disposition. Contra Burke, who holds that "beauty is, for the greater part, some quality in bodies, acting mechanically upon the human mind, by the intervention of the senses" (Enquiry, III, 12, 112), Kant argues that even when, "as experience teaches", a judgment of taste "is often enough rejected" by others, we should not be deterred from demanding that others assent to it. $^{52}$

However, Burke would never deny what Kant is claiming here, namely that the validity of a judgment of taste depends on the circumstances in which it is made: we can often be mistaken that our own judgment of taste is not based on any personal interest (KU, AA 05: 237.29-30), and we can merely claim that others will judge the object in the same way, if the circumstances are ideal. But Kant does make a very un-Burkean move, when contending that in a pure judgment of taste we also make a claim "to everyone's assent, as if it were an objective judgment." ${ }^{53}$ Hence, "That I am perceiving and judging an object with pleasure is an empirical judgment. But that I find the object beautiful, i.e., that I am entitled to require that liking from everyone as necessary, is an a priori judgment". ${ }^{54}$ For Kant, answering the question 'How are pure judgments of taste possible?' is part of "the general problem of

\footnotetext{
52 "[...] oft genug [...] wie die Erfahrung lehrt [...] abgewiesen wird" (KU, AA 05: 214.21-23)

53 "[...] mit einem Anspruche auf jedermanns Beistimmung, als ob es objectiv wäre." (KU, AA 05: 281.33-34)

54 "Es ist ein empirisches Urtheil: daß ich einen Gegenstand mit Lust wahrnehme und beurtheile. Es ist aber ein Urtheil a priori: daß ich inn schön finde, d. i. jenes Wohlgefallen jedermann als nothwendig ansinnen darf." (KU, AA 05: 28926-29)
} 
transcendental philosophy: How are synthetic judgments possible a priori?"55 (KU, AA 05: 289). Thus, "it is not the pleasure but the universal validity of this pleasure, perceived as connected in the mind with our mere judging of an object, that we represent a priori as a universal rule for the power of judgment, valid for everyone. ${ }^{~} 56$ Here Kant clearly breaks with Burke, for he maintains that pure judgments of taste are a priori rather than merely empirically valid.

What does this anti-Burkean move imply? When we are judging something as beautiful, Kant contends, it is as if we speak with a "universal voice [allgemeine Stimme]" (KU, AA 05: 216.17). This universal voice is, however, not empirical, but an Idea in the Kantian sense of the term, i.e. a transcendental Idea to which no empirical representation conforms (Ibid.). This is made especially clear in section 8 of the $\mathrm{KU}$, where Kant states that:

The judgment of taste itself does not postulate everyone's agreement (since only a logically universal judgment can do that, because it can adduce reasons); it merely requires this agreement from everyone, as an instance of the rule, an instance regarding which it expects confirmation not from concepts but from the agreement of others. Hence the universal voice is only an idea. [...] Whether someone who believes he is making a judgment of taste is in fact judging in conformity with that idea may be uncertain; but by using the term beauty he indicates that he is at least referring his judging to that idea, and hence that he intends it to be a judgment of taste. For himself, however, he can attain certainty on this point, by merely being conscious that he is separating whatever belongs to the agreeable and the good from the liking that remains to him after that. It is only for this that he counts on everyone's assent, and he would also be justified in making this claim under these conditions, if only he were not often to offend against these conditions and thereby make an erroneous judgment of taste. $^{57}$

\footnotetext{
55 "[...] unter das allgemeine Problem der Transscendentalphilosophie: wie sind synthetische Urtheile a priori möglich?" (KU, AA 05: 289.03-05)

56 "Also ist es nicht die Lust, sondern die Allgemeingültigkeit dieser Lust, die mit der bloßen Beurtheilung eines Gegenstandes im Gemüthe als verbunden wahrgenommen wird, welche a priori als allgemeine Regel für die Urtheilskraft, für jedermann gültig, in einem Geschmacksurtheile vorgestellt wird." (KU, AA 05: 289.22-26)

57 "Das Geschmacksurtheil selber postulirt nicht jedermanns Einstimmung (denn das kann nur ein logisch allgemeines, weil es Gründe anführen kann, thun); es sinnt nur jedermann diese Einstimmung an, als einen Fall der Regel, in Ansehung dessen es die Bestätigung nicht von Begriffen, sondern von anderer Beitritt erwartet. Die allgemeine Stimme ist also nur eine Idee [...] Daß der, welcher ein Geschmacksurtheil zu fällen glaubt, in der That dieser Idee gemäß Urtheile, kann ungewiß sein; aber
} 
An imputation of general assent in aesthetic pleasure is 'only' a transcendental idea. Against the rationalists, Kant insists that the required universal agreement in aesthetic judgments is always uncertain. One can reasonably claim that everyone should give his approval, but this requirement is not based on any (determinate) concepts, as rationalist philosophers argue to hold open the possibility for an ideal agreement or consensus. ${ }^{58}$ The evidence for (or against) my making a pure judgment of taste is uncertain, and it is not necessarily defeated by disagreement either, because I might have been wrong about the source of my own pleasure or because another may have not obtained the requisite abstraction. It is founded on the idea of the harmony of the cognitive powers - which is what Kant argues in $\S 9$.

This is obviously a crucial point. While Kant concurs with Burke that judgments of beauty cannot be based on the subsumption of an object under a determinate concept (such as perfection, as the rationalists hold), the claim to universal validity can neither be falsified inductively, but nor - and here again Kant disagrees with Burke - can it be verified empirically by basing one's own judgment on the occurrence of (a consensus of) other judgments of taste..$^{59}$ Moreover, Kant adds the following in $\S 8$ of the $\mathrm{KU}$ :

I use the expression universal validity [Gemeingültigkeit], by which I mean the validity that a representation's reference to the feeling of pleasure and displeasure may have for every subject, rather than the validity of a presentation's reference to the cognitive power. (We may also use the same expression for both the aesthetic and the logical quantity of a judgment, provided we add objective for the logical general validity

daß er es doch darauf beziehe, mithin daß es ein Geschmacksurtheil sein solle, kündigt er durch den Ausdruck der Schönheit an. Für sich selbst aber kann er durch das bloße Bewußtsein der Absonderung alles dessen, was zum Angenehmen und Guten gehört, von dem Wohlgefallen, was ihm noch übrig bleibt, davon gewiß werden; und das ist alles, wozu er sich die Beistimmung von jedermann verspricht: ein Anspruch, wozu unter diesen Bedingungen er auch berechtigt sein würde, wenn er nur wider sie nicht öfter fehlte und darum ein irriges Geschmacksurtheil fällte." (KU, AA 05: 216.13-28)

${ }^{58}$ This does not rule out the possibility that the content of aesthetic judgments involves concepts. What Kant claims is merely that (determinate) concepts do not form a sufficient basis rationally to impute our aesthetic appraisals to others. Aesthetic judgments are independent of the subsumption of the object under concepts - no more, no less.

${ }^{59}$ See also Fricke, Christel: Kants Theorie des reinen Geschmacksurteils, 12. 
[Allgemeingültigkeit] to distinguish it from the merely subjective one, which is always aesthetic. $)^{60}$

Subjective universality is not related to the content but to the epistemic status of the judgment ${ }^{61}$ : its extension is not (as in a logical judgment) a class of objects but "a class of possible human judges". ${ }^{62}$ This aesthetic universal validity cannot be based on the classification of the object under a concept: the step from 'This rose is beautiful' to 'All roses are beautiful' is not guaranteed by the first judgment's universal validity. Singularity and universality are, as it were, tied together in a pure judgment of taste: through a singular judgment the universal communicability of the feeling of pleasure is claimed, without any reference to (determinate) concepts. ${ }^{63}$

The problem of founding the pure aesthetic judgment's universal validity claim can only be tackled properly by introducing an important term that Kant uses for the first time in $\S$ 9 (on the question whether in a judgment of taste the feeling of pleasure precedes the judging of the object or the judging precedes the pleasure), viz. universal communicability (allgemeine Mittheilbarkeit). This is what needs to be accounted for, if we want to find the justification for the universality claim in the judgment of taste. ${ }^{64}$ Unfortunately, Kant has written one of the most confusing passages on this very issue. He states:

60 "[...] für welche ich auch den Ausdruck Gemeingültigkeit, welcher die Gültigkeit nicht von der
Beziehung einer Vorstellung auf das Erkenntnißvermögen, sondern auf das Gefühl der Lust und
Unlust für jedes Subject bezeichnet, gebrauche. (Man kann sich aber auch desselben Ausdrucks für
die logische Quantität des Urtheils bedienen, wenn man nur dazusetzt objective Allgemeingültigkeit
zum Unterschiede von der bloß subjectiven, welche allemal ästhetisch ist.)" (KU, AA 05: 214.33-37215.01-02)

${ }^{61}$ Although the aesthetic judgment is not cognitive, the subject's cognitive capacities (viz. understanding and imagination) are clearly involved. (Cf. supra)

${ }^{62}$ Guyer: Kant and the Claims of Taste, 132.

${ }^{63}$ As Paul Guyer remarks, "although aesthetics can never furnish determinate rules for the judgment of particular objects - a position that Kant would never abandon - it does yield some sort of indeterminate rules for the judgment of objects that are in some way a priori and therefore cannot be grounded in any merely empirical 'experience and observation' of human psychology, but must have some sort of transcendental foundation." See "Kant's Psychology of Aesthetics." In: Studies in the History and Philosophy of Science 39, 2008, 484. Guyer goes on to argue, however, that Kant's aesthetics - despite his own aims and intentions - remains within the confines of empirical psychology. ${ }^{64}$ See also Falk, Barry: "The Communicability of Feeling". In: Pleasure, Preference and Value: Studies in Philosophical Aesthetics. Edited by Eva Schaper. Cambridge 1983, 57-85. 
If the pleasure in the given object came first, and our judgment of taste were to attribute only the pleasure's universal communicability [allgemeine Mittheilbarkeit] to the representation of the object, then this procedure would be self-contradictory. For that kind of pleasure would be none other than mere agreeableness in the sensation, so that by its very nature it could have only private validity, because it would depend directly on the presentation by which the object is given. Hence it must be the capacity for being universally communicated of the mental state, in the given representation, which underlies the judgment of taste as its subjective condition, and the pleasure in the object must be its consequence. ${ }^{65}$

As Henry Allison notices ${ }^{66}$, Kant makes two rather puzzling statements. First, the pleasure is said to be the result of the aesthetic judgment; but how is this possible if the pleasure is also supposed to be the judgment's condition or ground? Secondly, aesthetic pleasure is argued to be the consequence of the universal communicability of the mental state in the judgment. How can the pleasure of taste be the consequence of the universal communicability of the mental state, when the latter is supposed to be pleasurable itself, at least in positive judgments of taste? This looks really circular. ${ }^{67}$ But, in fact, Kant could be defended by distinguishing between the act of judging or contemplating the object (Beurtheilung des Gegenstandes) and the judgment of taste (Geschmacksurtheil) as such. Judging the object obviously precedes the pleasure, but the latter precedes the actual judgment of taste. It not merely precedes it, it also forms the determining ground of the judgment of taste proper. Thus, according to Guyer, $\S 9$ contains the basic elements for a theory of aesthetic appraisal that consists of two logically - but not necessarily phenomenologically - distinct acts of reflection. First, an act of mere reflection in which pleasure is felt, and secondly, an act of aesthetic judgment proper, in which the cause of the pleasure is attributed to the harmonious

\footnotetext{
65 "Ginge die Lust an dem gegebenen Gegenstande vorher, und nur die allgemeine Mittheilbarkeit derselben sollte im Geschmacksurtheile der Vorstellung des Gegenstandes zuerkannt werden, so würde ein solches Verfahren mit sich selbst im Widerspruche stehen. Denn dergleichen Lust würde keine andere, als die bloße Annehmlichkeit in der Sinnenempfindung sein und daher ihrer Natur nach nur Privatgültigkeit haben können, weil sie von der Vorstellung, wodurch der Gegenstand gegeben wird, unmittelbar abhinge. Also ist es die allgemeine Mittheilungsfähigkeit des Gemüthszustandes in der gegebenen Vorstellung, welche als subjective Bedingung des Geschmacksurtheils demselben zum Grunde liegen und die Lust an dem Gegenstande zur Folge haben muß." (KU, AA 05: 216.35217.01-11; italics added)

${ }^{66}$ Allison: Kant's Theory of Taste, 111.

${ }^{67}$ See also Crawford, Donald: Kant's Aesthetic Theory. Madison 1974, 70 and Allison: Kant's Theory of Taste, $111 \mathrm{ff}$., to which I am indebted here.
} 
play of the faculties. On this reading too, however, Kant's apparent implication that the universal communicability of the mental state in judging the object is itself the source of the sensed pleasure is, as Guyer succinctly puts it, "obviously absurd", ${ }^{6}$ for it suggests that universal communicability is constitutive of aesthetic pleasure instead of merely playing a part in evaluating it. ${ }^{69}$ In the same section, however, Kant explicitly denies that pleasure in the ability to communicate one's mental state could account for the aesthetic pleasure in the beautiful. There is, Kant suggests, pleasure in the ability to communicate, but one cannot appeal to it to explain the transcendental necessity connected with the pure judgment of taste, since this is merely a "natural propensity [Hang] of man to sociability (empirical and psychological)"70. This is clearly a reference to Burke's view of beauty as "a social quality", belonging to the social passions that are comparable to "good company, lively conversations, and the endearments of friendship", which because of their social nature all "fill the mind with great pleasure" (Enquiry, I, 11, 43).

One way to explain Kant's remarkable implication that aesthetic pleasure is grounded in the universal communicability itself would be to qualify the aesthetic judgment, as Hannah Ginsborg does, as "a formal and self-referential judgment that claims, not the universal validity of an antecedently given feeling of pleasure, but rather its own universal validity with respect to the object". ${ }^{71}$ Thus a judgment of taste would be a judgment about the normativity of one's own mental state. The demand for assent is, then, merely the demand that others recognize this normativity, i.e., that I judge the object as it ought to be judged, namely as beautiful.

Yet one might wonder how self-referential judgments could avoid making use of concepts, and hence, whether Ginsborg's account does not illegitimately turn aesthetic

\footnotetext{
${ }^{68}$ Guyer: Kant and the Claims of Taste, 137.

${ }^{69}$ As Guyer contends, this would imply that in a solipsistic situation no one could take pleasure in a beautiful object. Only if there were the possibility of communication, would aesthetic pleasure be possible. See Guyer, Kant and the Claims of Taste, 137. This was actually Kant's anthropological view before he wrote the KU. See V-Lo/Blomberg, AA 24: 45f., where he argues, amongst other things, that taste cannot possibly be "separately solitary [abgesondert eigenthümlich]"; see also V-Lo/Philippi, AA 24: 353ff. and V-Anth/Collins, AA 15: 179f.. This also occurs, however, in texts written after the KU, as in, for instance, Anth, AA 07: 244 and MS, AA 06: 212. See further V-MP-L1/Pölitz, AA 28: 249ff., where he argues that the "universal sense" (allgemeine Sinn) underlying judgments of taste has to be identified with a "communal sense" (gemeinschaftliche Sinn), and also insists that "whoever does not come into a community has no communal sense" (AA 28: 249).

70 "[...] dem natürlichen Hange des Menschen zur Geselligkeit (empirisch und psychologisch) [...]" (KU, AA 05: 218.17-18)

${ }^{71}$ Ginsborg, Hannah: "Reflective Judgment and Taste”. In: Noûs 24, 1990, 72.
} 
judgments into intellectual judgments, i.e. judgments of cognition requiring concepts to determine the correctness of ascribing one's mental state to others, or - at least - into what Kant calls in his Logik Dohna-Wundlacken 'beautiful cognition' (schöne Erkenntnis), which is no longer based on the free play of the cognitive faculties, and hence is altogether different form a pure judgment of taste. ${ }^{72}$ Furthermore, it is hard to see how Ginsborg's view could allow for negative judgments of taste: if Kant meant the judgment of taste to be selfreferential, i.e. referring to the normativity or appropriateness of my mental state with regard to the object deemed beautiful, and if the pleasure of taste is really in the universal communicability of my pleasure, then there is no room for a universally communicable displeasure, since universal communicability is itself a source of pleasure. ${ }^{73}$

Ginsborg's view does not seem to be what Kant had in mind at all. It is hard to see how one can account for the intricacies of Kant's theory of aesthetic response without logically distinguishing between two acts of reflection. But it is equally difficult to see how Guyer's logical distinction can be translated into more phenomenological or 'psychological' terms. For, although disinterestedness does not form a legitimate basis for the universal communicability of the judgment of taste proper, it does operate as the affective 'symptom' of the fact that the pleasure must be attributed to the reciprocal quickening of the mental faculties that are operative in aesthetic judgments of taste - the "feeling of life" of the subject - and not to some idiosyncratic inclination or quirk: displeasure signals the disharmony, whereas pleasure signals the harmony of the two cognitive powers involved in aesthetic judging. It is in this sense that Kant's statement, quoted above, can be readily understood: "it must be the capacity for being universally communicated of the mental state [allgemeine Mittheilungsfähigkeit des Gemüthszustandes], in the given representation, which underlies the judgment of taste as its subjective condition, and the pleasure in the object must be its consequence" 74 .

\section{'Sensus Communis' and Primordial Solidarity}

Instead of qualifying this idea as hopelessly absurd, as Paul Guyer does, or (like Hannah Ginsborg) defining aesthetic judgments as self-referential, which deprives them of their disinterested nature - since pleasure in the universal communicability of the mental state cannot be disinterested but is (as Kant holds) a natural inclination - one might further

\footnotetext{
${ }^{72}$ Cf. V-Lo/Dohna AA, 24: 710: "Wenn Anschauung und Begriff zusammenstimmen zur Belebung der Erkenntnis selbst, so machen sie in uns ein Wohlgefallen und dann nennt man es schöne Erkenntnis. Man muss sich bemühen, dass Verstand und Einbildungskraft zu einem Geschäft zusammenstimmen. Dies ist aber nicht mehr Spiel."

${ }^{73}$ Allison: Kant's Theory of Taste, 115.

${ }^{74}$ Italics added.
} 
interpret Kant's claim in $\S 9$ as follows. Phenomenologically speaking, the purity of taste the disinterestedness of the experienced pleasure - is subjectively determined (as its subjective condition, Kant says) by the necessity of being universally communicable or shareable, i.e., by the 'signal' in the mind (Gemüth) that the felt pleasure (or displeasure) is universally communicable.

Hence the disinterestedness of the pleasure is the essential, a priori condition for the universal communicability of aesthetic judgments - without disinterestedness aesthetic judgments could not be universally shared, for disinterestedness, as we have seen, presupposes the purposeful 'free play' of the cognitive powers. Yet, on the other hand, the capacity for universal communicability is itself the ideal gauge to estimate whether the experienced pleasure is really disinterested or not. Hence, Kant writes: "the pleasure in the object must be its consequence", which means that only in and through its possible universal communication can it be estimated whether the felt pleasure is actually disinterested or not. So in this sense, and in this sense only, can the pleasure in an object be the consequence of "the capacity for being universally communicated of the mental state". This is what the judgment's exemplary necessity ultimately boils down to. Whether or not the pleasure is really pure pleasure, that is, the disinterested pleasure that grounds a pure judgment of taste, actually depends on the very possibility of universally communicating the aesthetic judgment, which is the ratio cognoscendi of the disinterestedness of the pleasure. That one can actually be fairly certain (though one will never be able to prove it by means of arguments) that the pleasure one experiences here and now is disinterested must be grounded in - though not caused by - the universal communicability of the mental state, or more precisely, in the affect that 'signals' whether or not the activity of the mental powers is universally communicable or not. And this affect, or rather this universally communicable mental state, of course, presupposes "a capacity for being universally communicated".

My alternative reading of Kant's rather opaque phrasing has the advantage of enabling us to account for, first, the specific productive role of the power of imagination in aesthetic judgments and, second, the important justificatory function of the idea (or 'ideal') of an aesthetic sensus communis. I am suggesting, then, that the affect accompanying our aesthetic exploration and appreciation, and signalling not merely the mental activity involved in aesthetic judging but also its potential for universal shareability, is intimately connected with a particular use of the faculty of imagination that Burke does not take into consideration. Instead of operating in a purely reproductive ('mnesic') way, in aesthetic reflection our imagination operates productively, Kant argues, thus surpassing the constraints of empirical knowledge, and particularly (what Kant calls) "the laws of association" that are operative in empirical knowledge. Whilst, for Burke, imagination "can only vary the disposition of those ideas which it has received from the senses" and "can only be pleased or displeased with the 
images from the same principle on which the sense is pleased or displeased with the realities" (Enquiry, 'Introduction on Taste', 18), for Kant, imagination can create a "second nature", consisting (for instance) of kindred representations, aesthetic attributes, a host of unbounded configurations, which cannot be grasped by determinate concepts and enables us to think and feel in new ways about a myriad of things. This "free play" of the imagination is, moreover, responsible for the enlivening affective experience which a beautiful object can offer. The productive imaginative capacity is an a priori condition for aesthetic judgment and, hence, must be universally communicable.

This a priori universal communicability (or shareability) does not, however, function merely as an addition to or specification of the other transcendental "moments" that Kant distinguishes. It is far more crucial than that. The qualification of pure aesthetic pleasure as "disinterested" might suffice in distinguishing it from mere sensory pleasure in the agreeable - at least, if we acknowledge pure pleasure's intentional nature (Cf. supra) - but it cannot fully legitimate the autonomy (or "heautonomy") of aesthetic judgment, let alone its universal validity. The demand for universal communicability, on the other hand, can serve as the basis for the universal validity of the aesthetic judgment, since the aesthetic sensus communis upon which this demand is grounded ultimately refers to the Idea of the "supersensible substratum of nature", which Kant meaningfully calls "the single key [einzige Schlüssel] to the mystery of this faculty" 75 of taste. This shows why the possibility of universal communication is more crucial to the validity of judgments of taste than has usually been assumed. ${ }^{76}$ For the fourth moment of Kant's Analytic of the Beautiful characterises the exemplary necessity of the assent of all to an aesthetic judgment. Kant thus intimately links singular subjectivity - which is based upon disinterested pleasure, and which is in its turn grounded in the free harmonious play of imagination and understanding - with a peculiar kind of necessity, which is not logical but "exemplary" or "subjective" (KU, AA 05: 237.8; 237.20ff.). ${ }^{77}$ Kant can connect both consistently only by presupposing some basic principle in

\footnotetext{
75 "[...] als der einzige Schlüssel der Enträthselung dieses uns selbst seinen Quellen nach verborgenen Vermögens [...]"(KU, AA 05: 341.09-10)

${ }^{76}$ A notable exception is Longuenesse, Béatrice: Kant on the Human Standpoint. Cambridge 2005, esp. chapter 10.

${ }^{77}$ In the Anthropology from a Pragmatic Viewpoint, Kant even argues that "Taste [...] concerns the communication of our feeling of pleasure or displeasure to others, and includes a susceptibility, which this very communication affects pleasurably, to feel a satisfaction (complacentia) about it in common with others (sociably). Now satisfaction that can be considered valid not merely for the subject who feels it but also for everybody else, that is, universally valid, must contain necessity (of this satisfaction). So, in order to be considered universally valid, this satisfaction must contain a a priori principle." ["Der Geschmack [...] geht auf Mittheilung seines Gefühls der Lust oder Unlust an Andere
} 
human nature, which is a disposition to feel (hence the "affective signal" that I mentioned above) that is arguably "common to all", and is yet not merely "the effect arising from the free play of our cognitive faculties"78, but also, as Allison aptly puts it, "a sense (or feeling) for what is universally communicable, which can also be assumed to be universally shared. Otherwise expressed, it is a shared capacity to feel what be universally communicable". ${ }^{79}$ However, contra Allison, ${ }^{80}$ only when we take into account Kant's assumption of an aesthetic common sense can we properly legitimate the universal communicability of pure judgments of taste. ${ }^{81}$ And although the arguments that Kant provides for the necessary existence of such an aesthetic sense, which is assumed to be common to all, are deeply flawed ${ }^{82}$, it does help us fully to grasp the meaning of the above mentioned puzzling statement in $\S 9$, which clearly refers to a (transcendental) capacity that enables us properly to distinguish between what is universally communicable and what is not, and is constitutive for our pure aesthetic pleasure. $^{83}$

Thus, the exemplary necessity of pure judgments of taste, that is to say, the idea that we can legitimately claim to have judged the object as it ought to be judged, if we could be certain that our judgment is a pure judgment of taste, is grounded in a principle or Idea that

und enthält eine Empfänglichkeit, durch diese Mittheilung selbst mit Lust afficirt, ein Wohlgefallen (complacentia) daran gemeinschaftlich mit Anderen (gesellschaftlich) zu empfinden. Nun ist das Wohlgefallen, was nicht blos als für das empfindende Subject, sondern auch für jeden Anderen, d. i. als allgemeingültig betrachtet werden kann, weil es Nothwendigkeit (dieses Wohlgefallens), mithin ein Princip desselben a priori enthalten muß, um als ein solches gedacht werden zu können"] (Anth, AA 07: 244.3-11).

78 “[...] die Wirkung aus dem freien Spiel unserer Erkenntnißkräfte [...]"(KU, AA 05: 238.13-14)

${ }^{79}$ Allison: Kant's Theory of Taste, 149. I here strongly disagree with Gundula Felten, who contends that "sensus communis can be characterized as an "argumentative and theoretical sense for that which is common to everyone". (Felten, Gundula: Die Funktion des 'sensus communis' in Kants Theorie des ästhetischen Urteils. München. 2004, 196.)

${ }^{80}$ Henry Allison denies that Kant's discussion of the 'common sense' in $\S 21$ is part of the attempted 'Deduction of Taste'. See his Kant's Theory of Taste, 149-155.

${ }^{81}$ See also Fricke, Christel: Kants Theorie des reinen Geschmacksurteils, 161-176; Kemal, Salim: Kant's Aesthetic Theory. London 1997, 70-72; Lyotard, Jean-François: Lessons on the Analytic of the Sublime, Stanford 1994, 191-224; Savile, Anthony: Aesthetic Reconstructions: The Seminal Writings of Lessing, Kant, and Schiller. Oxford 1987, 142-161.

${ }^{82}$ See Allison: Kant's Theory of Taste, 150ff. See also Guyer: Kant and the Claims of Taste, 248-273.

${ }^{83}$ See also Foisy, Susanne: "Le sensus aestheticus est-il 'quasi-transcendental'? (Remarques sur une apologie et un double visage)". In: Kants Ästhetik / Kant's Aesthetics / L'esthétique de Kant. Edited by Herman Parret. Berlin 1998, $282 f$. 
cannot be recognized through mere "psychological observation" but is a priori": it "springs from reason", and even "comes under the principle of duty". ${ }^{85}$ Its existence cannot, however, be dogmatically stated, as the rationalists assume with respect to the existence of God, but we must still presuppose this principle a priori to account for the quasi-apodictic nature of pure aesthetic judgments.

The a priori principle functions as an "ideal norm", which everyone ought to observe when judging an object as beautiful, and in this respect taste even "has a tendency toward the external advancement of morality" ${ }^{\prime 66}$. As the necessity of pure aesthetic judgments is merely "exemplary", its universal validity cannot be based on an objective rule or principle. It cannot be based upon some moral norm either, however, since this would threaten the autonomy of the judgment of taste, nor on an empirical sensation, as Burke argues. For, although Burke and other empiricists may be right that pure judgments of taste operate without determinate rules, they are still governed by a regulative Idea, that is, a "universal voice", which is (as Kant insists) ultimately "supersensible". ${ }^{87}$ This noumenal principle arguably ${ }^{88}$ underlies not only the distinctive characteristics of a pure judgment of taste, but is also its ultimate "point of reference for the harmonious accord of all our faculties of cognition - the production of which accord is the ultimate end set by the intelligible basis of our nature" ${ }^{\text {" }}$. In $\S 40$ Kant, therefore, meaningfully claims that "taste can be called a sensus communis more legitimately than can sound understanding, and that the aesthetic power of judgment deserves to be called a shared sense more than does the intellectual one", and adds that "we could even define taste as the ability to judge something that makes our

\footnotetext{
${ }^{84}$ Hence, it cannot merely be a "common sensibility", nor a necessary prefiguration of a "universal consensus of respect for the moral law", as Lories suggests. See Lories, Danielle: "Génie et goût: complicité ou conflit?". In: Kants Ästhetik / Kant's Aesthetics / L'esthétique de Kant. Edited by Herman Parret. Berlin 1998, 577ff.

${ }^{85}$ Anth, AA 07: 244: "[...] welches [...] mithin aus der Vernunft entspringen muß [...] steht [...] unter dem Princip der Pflicht".

86 "[...] eine Tendenz zur äußeren Beförderung der Moralität." (Anth, AA 07: 244.16-17)

${ }^{87}$ The a priori idea of the supersensible in us does not, however, refer to God or God's purposive creation, as e.g. in Moses Mendelssohn, but to the indeterminate concept of that which grounds "the subjective purposiveness of nature for the power of judgment", which (as Kant argues) may refer to the "supersensible substrate of humanity" (Cf. KU, AA 05: 340.21-22; see also KU, AA 05: 341.09-10.) ${ }^{88}$ For excellent criticism of Kant's arguments for the existence of a supersensible substrate, see Guyer, Paul: Kant and the Claims of Taste, chapter 10. Allison defends it in Kant's Theory of Taste, chapter 11.

89 "[...] folglich das, auf welches in Beziehung alle unsere Erkenntnißvermögen zusammenstimmend zu machen, der letzte durch das Intelligible unserer Natur gegebene Zweck ist [...]" (KU, AA 05: 344.14-16)
} 
feeling in a given representation universally communicable without mediation by a concept."90 This move to the "intelligible basis of our nature" also explains how beauty, while being logically distinct from morality, can none the less present moral ideas, and promote not only a morally significant capacity but also some sort of a priori communality among aesthetic subjects. ${ }^{91}$

Here Kant truly offers his definitive rebuttal of Burke's empiricist aesthetics. Only if we recognise the value of the exemplary necessity of judgments of beauty can we see the real scope of Kant's response to Burke's empiricism: even if Burke and other empiricists do recognise some kind of shared human nature or general standard of taste, they cannot account for beauty's a priori demand to be universally and necessarily communicated or shared. To be able to sense or feel that we are judging the aesthetic object as we ought to can neither be explained adequately in empirical terms, nor can we be completely certain to have made a pure judgment of taste, since we often mistakenly think that we have judged an object in a purely disinterested way, whereas we were really led by some hidden interest or personal quirk (Cf. KU, AA 05: 216; 05: 237; 05: 290f.). Yet the whole point of Kant's response to Burke is that if we presuppose that pure judgments of taste exist, then we have to account for their possibility in transcendental terms, for they are judgments "which, merely on the basis of one's own feeling of pleasure in the object, independently of the object's concept, judges this pleasure as attached to the representation of that same object in every other subject, and does so a priori, i.e., without having to wait for the assent of others". ${ }^{92}$ Contra Burke and other empiricists, Kant clearly assumes that we are capable of nonconceptual purposive sensibility and sociability, and that the standard for it is a priori. From this point of view, Kant moves towards a theory of beauty close to his rationalist predecessors.

However, contra rationalist philosophers, Kant also (rightly) maintains that what is at stake in the favour (or Gunst) of (natural) beauty "is not what nature is or even what it is for

\footnotetext{
90 "[...] daß der Geschmack mit mehrerem Rechte sensus communis genannt werden könne, als der gesunde Verstand; und daß die ästhetische Urtheilskraft eher als die intellectuelle den Namen eines gemeinschaftlichen Sinnes führen könne [...] Man könnte sogar den Geschmack durch das Beurtheilungsvermögen desjenigen, was unser Gefühl an einer gegebenen Vorstellung ohne Vermittelung eines Begriffs allgemein mittheilbar macht, definiren." (KU, AA 05: 295.21-29)

${ }^{91}$ See KU, AA 05: 267.35-37. See also Felten: Die Funktion des 'sensus communis' in Kants Theorie des ästhetischen Urteils, chapter 2.

92 “[...] das bloß aus dem eigenen Gefühl der Lust an einem Gegenstande unabhängig von dessen Begriffe diese Lust, als der Vorstellung desselben Objects in jedem andern Subjecte anhängig, a priori, d. i. ohne fremde Beistimmung abwarten zu dürfen, beurtheilte" (KU, AA 05: 288.28-31).
} 
us as a purpose, but how we take it in."93 This important 'empiricist' qualification prevents Kant's aesthetics from turning into sheer rationalism. For what is at stake in judging the nonconceptual unity of an object shall not be based on the objective purposiveness of nature, but rests on the universal yet subjective harmony of imagination and understanding. The exemplary necessity of this kind of judgment is, again, of paramount importance, for otherwise Kant's aesthetics would end up in empiricist psychology. Without recourse to an a priori supersensible ground and without linking this ground to the purposiveness of nature in general, Kant would never have been able to surpass Burke's empiricist aesthetics.

That we are, somehow, able to feel that our judgment legitimately demands others to assent cannot be explained in merely empirical terms. On the other hand, that I am judging the object as it ought to be judged cannot, however, be grounded in the dogmas of (Christian) religion and rationalist metaphysics either, and Kant will, hence, rightfully insist that the ability to distinguish between what is universally valid and what is not, is founded upon an a priori principle, which guarantees the freedom and autonomy of pure taste. In this sense, we might argue that pure judgments of taste exemplify ${ }^{94}$ their supersensible ground. Therefore, again, our "ability to judge a priori the communicability of the feelings", when confronted by a beautiful object, indeed presupposes "a capacity for being universally communicated of the mental state", i.e. a transcendental capacity that not merely yields an a priori basis for pure judgments of beauty but also increases the cognitive, moral and (I would suggest) social values of the beautiful and immensely enriches our experience of it. ${ }^{95}$ As Allen Wood justly argues, pure aesthetic pleasure is "a pleasure we can share, and expect to share, with all subjects who entertain the same representations in a purely aesthetic manner [...] And because we are also sociable beings, who take pleasure in being able to communicate with others of our kind, there is added to our pleasure in the mutual animation of our faculties also

\footnotetext{
93 “[...] kommt es nicht darauf an, was die Natur ist, oder auch für uns als Zweck ist, sondern wie wir sie aufnehmen." (KU, AA 05: 350.14f.; italics added)

${ }^{94}$ In Nelson Goodman's sense of 'possession plus reference'. See Goodman, Nelson: Languages of Art. Indianapolis. 1976, 53.

${ }^{95}$ That the supersensible is only cognizable through "freedom's formal laws" does not entail that pure judgments of taste cannot be exemplary instances of the supersensible substrate, whose assumption arguably validates their universality. Even without becoming aware of beauty's symbolising of morality can we thus 'understand' what grounds both our aesthetic judgments' universal communicability and the aesthetic common sense.
} 
a pleasure of sociability - the pleasure of having sensations that are universally communicable, sharable with others." 96

Our various experiences of beauty can thus have a broader social significance in terms of what I would call 'primordial solidarity'. By this, I mean that the beautiful is an affective experience which qua aesthetic experience is logically distinguishable from those connected with the vicissitudes of everyday life, but which, if understood correctly, reveals a foundation in social structures that are immanent to, but customarily concealed within, that life. Judgments of beauty do not exist in a vacuum, but have intimate connections with fundamental social aspects of human life. They reveal some kind of primordial cosubjectivity $^{97}$ that is not based on conceptual knowledge but presupposes a certain inherent awareness that others ought to assent to our judgments of beauty, which furthers both our aesthetic satisfaction and our capacities of sociability and communication. I am suggesting, then, that when we enjoy an aesthetic experience and understand what is involved in it, at the same time a horizon of universal communality is disclosed, which not only gives an unmatched depth and intensity to our experience, but may also cultivate deep solidarity with, and respect for, others who are equally capable of appreciating pure beauty.

\section{Conclusion}

I have argued that, in the KU, Kant is profoundly concerned with Burke's empiricism, and that recognising that his transcendental critique of the judgment of beauty is, to a certain extent, structured around the task of responding to this Burkean form of empiricism may be a useful way to illuminate the significance of both their contributions to philosophical aesthetics.

A number of different traits run through Kant's responses to the Burkean form of physiological and empiricist analysis of aesthetic pleasure that he diagnoses. One key feature of his response is to argue that Burke's empiricist method cannot account for the qualitative difference between the agreeable and the beautiful, for it can neither properly acknowledge the disinterestedness of the pleasure upon which a judgment of beauty is based nor adequately account for the cognitive value of beauty, which is linked with the "free harmonious play" of imagination and understanding, and crucially involves reflection upon

\footnotetext{
${ }^{96}$ Wood, Allen: Kant. Malden 2005, 156. See also Guyer, Paul: "Pleasure and Society in Kant's Theory of Taste". In: Essays in Kant's Aesthetics. Edited by Ted Cohen \& Paul Guyer. Chicago 1982, 21-54.

${ }^{97}$ Hence, I would suggest that Kantian aesthetics does not imply a mere "subjectivization of aesthetics", as Gadamer urges. See Gadamer, Hans-Georg: Truth and Method. New York. 1999, 4281 , but rather surpasses the egocentric tendencies of empiricist aesthetics. See also Kant's discussion of the "virtues of social intercourse" (Umgangstugenden) in MS, AA 06: 473f.
} 
the pleasure's ground and the object's form. Another characteristic of Kant's approach is essentially to argue that Burke's psycho-physiological analysis of beauty should ultimately be refuted, since it cannot account for the aesthetic judgment's a priori claim to universal assent, and hence fails adequately to characterise beauty's "universal voice". Without recourse to an a priori ground of human nature and without linking the "supersensible substrate" to the purposiveness of nature in general, the freedom and heautonomy of taste cannot be fully legitimated. For, that we are capable of genuinely sharing the pleasure of beauty presupposes a capacity to distinguish between what is universally communicable and what is not, namely, aesthetic common sense, and this human capacity in its turn discloses a profound primordial solidarity among aesthetic subjects. 